\title{
PENGARUH PEMBELAJARAN KEWIRAUSAHAAN DAN MOTIVASI BERPRESTASI TERHADAP MINAT BERWIRAUSAHA MAHASISWA PENDIDIKAN AKUNTANSI FPEB UNIVERSITAS PENDIDIKAN INDONESIA
}

\author{
Alif Fauzia Restiadi' ${ }^{1}$, Kurjono², Yana Setiawan ${ }^{3}$ \\ Program Studi Pendidikan Akuntansi FPEB UPI \\ Bandung, Indonesia

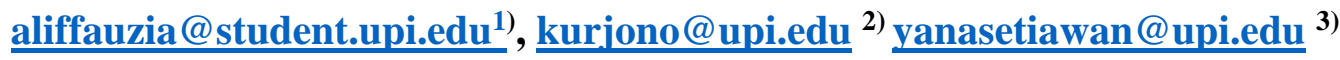

\begin{abstract}
This reseach present the lack of entrepreneurial intention in student, so the impact that has caused is an increase in the number or unemployment rate in Indonesia. The aims of this research are to describe the effect of entrepreneurial learning, achievement motivation and entrepreneurship intention, and also the effect of effect of entrepreneurial learning, achievement motivation on entrepreneurship intention of Accounting Education FPEB major student period 2016, 2017 and 2018 at Indonesia University Of Education (Universitas Pendidikan Indonesia). Using Theory Behavior Planed, this research use descriptive and verification methods. The population of this study consist 254 Accounting Education, there are student class 2016, 2017, and 2018, with research sample of 155 Students. The research use random sampling method. The instrument validity was assessed by product moment correlation and the reliability by cronbach's alpha, using questionnares as a data collection technic. The classic assumption test includes the normality test, the linearity test, the multicollinearity test, and the heteroscedasticity test. All data calculation is done by using Microsoft Statistical Product and Service Solution (SPSS) v25 and Microsoft excel 2016. From the calculation results of the test on each variable entrepreneurial learning and, achievement motivation the result of $t$-test shows $t_{\text {statistic }}>t_{\text {tabel }}$, i.e. variable entrepreneurial learning obtained by $\mathrm{t}_{\mathrm{statistic}: 4.297}>\mathrm{t}_{\mathrm{tabel}: 1.97569}$ and variable achievement motivational obtained by $t_{\text {statistic: } 4.572}>\mathrm{t}_{\text {tabel }}$ : 1.97569. The result of study showed that entrepreneurial learning and achievement motivation has a positive effect on entrepreneurship intention of Students Accounting Education FPEB period 2015, 2016 and 2017 at Indonesia University of Education (Universitas Pendidikan Indonesia). The suggestions that can be given from this research are to increase the mindset, knowledge, skills and participation in learning and dare to start a business because it's important in increasing interest in entrepreneurship.
\end{abstract}

Keywords:Entrepreneurial Learning, Achievement Motivation and Entrepreneurship Intention

\section{PENDAHULUAN}

Memasuki abad ke-21, tantangan dan permasalahan kehidupan manusia terusmenerus berkembang seiring dengan perkembangan ilmu pengetahuan, teknologi, seni, dan ekonomi. Tantangan dan konflik tersebut diperlukan manusia yang berkualitas, menjadi penentu kearah yang lebih baik. Menurut Salahuddin et al., (2018) Pemerintah dituntut untuk menciptakan dan mengoptimalkan sumber daya manusia dalam berbagai bidang sesuai dengan kebutuhannya. Analisis penelitian ini mendasar dari teori pemberdayaan SDM 
sesuai dengan kebutuhan untuk meningkatkan kualitas pendidikan menuju SDM yang unggul dan kompetitif dimulai dari peningkatan kualitas kinerja tenaga pendidik yang profesional.

Tuntutan pembangunan menuju kesejahteraan dengan cara menciptakan sumber daya manusia yang berkualitas dan memiliki keterampilan serta berdaya saing tinggi

Pendidikan merupakan usaha agar manusia agar mampu mengembangkan potensi diri melalui kegiatan pembelajaran dan atau cara lain yang dikenal dan diakui oleh masyarakat. Sesuai dengan fungsi dan tujuan pendidikan nasional yang dinyatakan dalam (UndangUndang Republik Indonesia No. 20, 2003) tentang Sistem Pendidikan Nasional. Fungsi dan tujuan pendidikan nasional menurut UU Sisdikanas, Bab II, Pasal 3 dirumuskan sebagai berikut,

Pendidikan nasional berfungsi mengembangkan kemampuan dan membentuk watak serta peradaban bangsa yang bermartabat dalam rangka mencerdaskan kehidupan bangsa, bertujuan untuk mengembangkan potensi peserta didik agar menjadi manusia yang beriman dan bertaqwa kepada Tuhan Yang Maha Esa, berakhlak mulia, sehat, berilmu, cakap, kreatif, mandiri, dan menjadi warga Negara yang demokratis dan bertanggung jawab. Untuk itu, seluruh komponen bangsa wajib mencerdaskan kehidupan bangsa yang merupakan salah satu tujuan Negara Indonesia.

Keadaan ini tentunya menjadi tantangan sendiri bagi pemerintah dan dunia pendidikan. Pendidikan diharapkan mampu menciptakan manusia - manusia unggul bukan hanya dalam penguasaan ilmu, tetapi juga dalam mempersiapkan untuk memasuki dunia kerja akan tetapi belum terealisasikan secara optimal. Sama halnya dengan lulusannya diharapkan dapat memenuhi tuntutan dunia usaha akan tenaga kerja. Namun saat ini lulusan perguruan tinggi lebih memilih bekerja sebagai karyawan atau pegawai. Karena rata-rata universitas mampu untuk melahirkan sarjana yang siap kerja dan bukan sarjana yang siap menciptakan lapangan pekerjaan.

Indonesia merupakan salah satu negara berkembang, yang dimana jumlah masyarakat yang terdidik senantiasa mengalami peningkatan, akan tetapi tidak diimbangi dengan peningkatan jumah lapangan pekerjaan yang tersedia. Kondisi diatas berdampak pada peningkatan jumlah pengangguran dan merupakan masalah yang sangat mendesak untuk diselesaikan. Saat ini jumlah lulusan pada jenjang sarjana mengalami peningkatan setiap tahunnya, tetapi sedikit pula yang langsung mendapatkan pekerjaan. Handayani, (2015) megatakan ada tiga faktor dasar yang 
menjadi permasalahan tingginya tingkat pengangguran sarjana di Indonesia yaitu: ketidaksesuaian hasil yang dicapai antara pendidikan dengan lapangan kerja, ketidakseimbangan permintaan dan penawaran terhadap jasa manusia, kualitas sumber daya manusia itu sendiri.

Penggaguran dengan berlatar belakang pendidikan tinggi masih sangat banyak, apalagi ditambah dengan minat berwirausaha yang rendah hal ini sangat tidak baik apabila dibiarkan begitu saja. Karena akan membuat angka pengangguran yang berlatar belakang pendidikan tinggi akan semakin meningkat. Menurut Hendro dalam (Hijriana dan Purwaningsih, 2016) menyebutkan bahwa tingkat pengangguran didunia dan di Indonesia sangat tinggi. Akhir tahun 2016 angka pengagguran di Indonesia sudah mencapai puluhan juta orang. Hal ini mengakibatkan lulusan perguruan tinggi merasa sulit mencari pekerjaan Situasi persaingan dunia kerja juga diperberat oleh lulusan baru yang menjadi pesaing untuk mendapatkan kesempatan kerja yang sama, hal ini menarit minat pengelola perguruan tinggi dalam meningkatkan minat mahasiswa untuk berwirausahan

$\begin{array}{ccr}\text { Maka } & \text { didalam } & \text { pendidikan } \\ \text { kewirausahaan akan } & \text { menanamkan } \\ \text { kepribadian kreatif dan inovatif yang }\end{array}$

memiliki jiwa dan sikap kewirausahaan yang nantinya sumber daya manusia lulusan lembaga pendidikan tinggi cenderung lebih senang berusaha mandiri dengan membuka usaha baru dan menciptakan lapangan pekerjaan bagi dirinya dan orang lain. "Salah satu alternatif untuk memecahkan masalah pengangguran adalah dengan memberdayakan masyarakat dan kelompok terdidik melalui program kewirausahaan yang diharapkan mampu berkontribusi dalam penyerapan tenaga kerja sehingga mengurangi pengangguran dan beban negara" (Primandaru, 2017).

Berdasarkan data BPS survei angkatan kerja nasional (sakernas) 2017 2019 tentang Pengangguran terbuka menurut pendidikan tertinggi yang ditamatkan terjadi fluktuasi pada tingkat pengangguran dari tahun ke tahun. Krisis ekonomi 1998 juga telah ikut menyumbangkan angka pengangguran di Indonesia. Pada tingkat universitas untuk tahun 2018 bulan februari mengalami kenaikan pengangguran sebesar 2,65\%, sementara data terbaru pada tahun 2018 bulan agustus mengalami penurunan tingkat pengangguran sebesar 1,06\%. Dan ditahun 2019 terjadi kenaikan lagi pada tingkat pengangguran sebesar 1,89\%. Permasalahan yang timbul adalah masih 
banyaknya lulusan perguruan tinggi yang belum bekerja.

Fenomena ini diakibatkan oleh rendahnya minat berwirausaha di Indonesia menjadi pemikiran serius berbagai pihak, baik pemerintah, dunia pendidikan, dunia industri, maupun masyarakat. Jika kondisi seperti ini berlanjut, maka pada saat nanti banyak penggaguran terdidik.

Berbagai upaya dilakukan untuk menumbuhkan jiwa kewirausahaan terutama merubah mindset yang selama ini hanya berminat sebagai pencari kerja (job seeker) apabila menyelesaikan pendidikan mereka. Hal ini merupakan tantangan bagi Lembaga Pendidikan sebagai penghasil lulusan. Semua perguruan tinggi di Indonesia telah memasukkan mata kuliah kewirausahaan ke dalam kurikulum sebagai salah satu mata kuliah yang wajib ditempuh oleh mahasiswa. Pendidikan kewirausahaan tidak hanya memberikan landasan teoritis mengenai konsep kewirausahaan melainkan membentuk sikap, perilaku, dan pola pikir (mindset) seorang wirausahawan (entrepreneur).

Universitas Pendidikan Indonesia sebagai salah satu lembaga pendidikan tinggi di Indonesia sudah menerapkan program Kewirausahaan bagi mahasiswanya dengan mengadakan business plan. Salah satu program studi yang mengadakan pembelajaran Kewirausahaan adalah program studi pendidikan akuntansi, walapun terdapat mahasiswa pendidikan akuntansi yang sudah mempelajari Kewirausahaan hanya sebagian mahasiswa yang memiliki minat kewirausahaan. Hal ini dibuktikan oleh data pra penelitian yang dilakukan oleh peneliti pada mahasiswa Pendidikan Akuntansi 2016, 2017 dan 2018 mengambil dari data 90 mahasiswa Pendidikan Akuntansi sebagai sampling aksidental yang sudah menempuh pembelajaran Berwirausaha pada semester ganjil untuk mengambarkan minat berwirausahanya, hasil pra penelitian menyatakan hanya $2 \%$ mahasiswa yang memiliki minat berwirausaha tinggi sebagiannya dinyatakan memiliki minat berwirausaha rendah sebesar $54 \%$ dan sedang 44\%. Untuk lebih jelasnya dinyatakan dalam Tabel sebagai berikut:

Table 1.1

Minat Kewirausahaan Mahasiswa Pendidikan Akuntansi Angkatan 2015-2016

\begin{tabular}{lll}
\hline KRITERIA & FREKUENSI & PRESENTASI \\
\hline RENDAH & 1 & $2 \%$ \\
SEDANG & 40 & $44 \%$ \\
TINGGI & 49 & $54 \%$ \\
TOTAL & 90 & $100 \%$ \\
\hline
\end{tabular}

Sumber: Hasil Angket Pra Penelitian (Data Diolah)

Berdasarkan Tabel 1.1 menunjukan bahwa minat kewirausahaan pendidikan akuntansi 
menbuktikan bahwa minat wirausaha di pendidikan akuntansi UPI adalah rendah.

Pada dasarnya minat berwirausaha dipengaruhi oleh banyak faktor seperti yang diutarakan Ajzen, (2005) Theory of Planned Behaviour menyatakan bahwa minat seseorang untuk melakukan suatu perilaku, TPB mengidentifikasikan tiga faktor yang mempengaruhi minat berwirausaha,dengan dua faktor mengambarkan keinginan untuk melakukan sikap pribadi (personal attitude) terhadap hasil perilaku dan norma-norma sosial (subjective norm) yang dirasakan. Dan faktor ketiga adalah kontrol perilaku yang dirasakan (perceived behavioral control), mencerminkan persepsi bahwa perilaku dikontrol secara pribadi.

Berdasarkan hal tersebut maka salah satu faktor berkembang atau tidaknya minat berwirausaha ditunjukan dalam pembelajaran kewirausahaan yang ditunjukan oleh faktor motivasional yang mempengaruhi perilaku tertentu yang dikaitkan dengan minat berwirausaha. Hal ini sejalan dengan Theory of Planned Behavior bahwa intensi/minat diasumsikan sebagai faktor motivasional atau pendorong yang mempengaruhi perilaku tertentu. Terdapat beberapa faktor yang mempengaruhi minat berwirausaha dua diantaranya yaitu pembelajaran dan motivasi.
Adapun yang dikatakan oleh (Purwanto, 2002:16.) bahwa: Untuk membentuk sikap kewirausahaan, termasuk didalamnya minat berwirausaha, adakah mulai dengan tahap pemahaman teori, studi kasus, dan pemberian motivasi, ketiga tahapan ini dapat dilakukan dilingkungan sekolah.

Suherman, (2010) dan Nana Supriatna, (2012) mengatakan Pembelajaran Kewirausahaan, diartikan sebagai proses memberikan ilmu kewirausahaan kepada peserta didik dengan tujuan tertentu yaitu untuk menumbuhkan minat wirausaha serta mencetak wirausaha baru. Dalam mengukur seberapa besar pembeajaran kewirausahaan dengan menggunakan indikator sebagai berikut yaitu adanya materi pembelajaran, tujuan pembelajran, metode pembelajaran, kemampuan guru, sumber pembelajaran, stategi pembelajaran, media pembelajaran, evaluasi pembelajaran, pengalaman langsung Oemar Hamalik dalam (Pratomo et al., 2018) dan (Suherman, 2010).

Motivasi Berprestasi, merupakan kondisi fisiologis dan psikologis yang terdapat dalam diri siswa yang mendorongnya untuk melakukan aktivitas tertentu guna mencapai tujuan tertentu Djaali, (2014). Menurut McChelland (dalam Danim, 2004 : 33) untuk mengukur seberapa besar motivasi berprestasi dengan 
menggunakan indikator sebagai berikut yaitu adanya berani mengambil resiko moderat, menghendaki umpan balik segera (Immediate Feedback), keberhasilan diperhitungkan secara teliti, mengintegralkan tugas.

Minat Berwirausaha yaitu suatu landasan yang paling meyakinkan dalam mendukung proses belajar, di mana minat tidak akan terjadi begitu saja, melainkan sesuatu yang dapat dipelajari. Menurut (Ramayah dan Harun, 2005) untuk mengukur seberapa besar motivasi berprestasi dengan menggunakan indikator sebagai berikut yaitu jalur usaha sendiri, karir berwirausaha, perencanaan usaha.

Berdasarkan uraian diatas dapat disimpulkan dalam penelitian kali ini dijelaskan mengenai pengaruh pembelajaran kewirausahaan dan motivasi berprestasi terhadap minat berwirausaha, bahwa faktor yang menpengaruhi minat berwirausaha berdasarkan uraian tersebut didasari oleh Theory of Planned Behavior adalah pembelajaran kewirausahaan termasuk kedalam ranah norma subjektif (subjective norms). Maka apabila semakin baik pembelajaran kewirausahaan seseorang, maka akan semakin tinggi minat dan begitupun sebaliknya. Motivasi berprestasi yang termasuk dalam kedalam ranah sikap pribadi (personal attitude) diasumsikan sebagai faktor motivasional atau pendorong yang mempengaruhi perilaku tertentu, apabila seseorang memiliki motivasi yang tinggi maka akan meningkatkan minatnya juga dalam berwirausaha dan begitu pula sebaliknya.

Berdasarkan Theory of Planned Behavior Ajzen, (2005), penelitian mengenai pembelajaran kewirausahaan dan motivasi berpretasi relatif belum banyak dilakukan dan dalam beberapa penelitian sebelumnya masih terdapat perbedaan hasil penelitian. Penelitian yang dilakukan oleh Kim dan Park (2019) menunjukan kesimpulan bahwa pembelajaran kewirausahan memiliki dampak positif dan signifikan terhadap minat berwirausaha dan penelitian ini menujukan strategi dalam meningkatkan bagaimana lembaga pendidikan dan pendidik dapat merancang program wirausaha agar selama pembelajan menghasilkan minat positif dalam berwirausaha. Hasil penelitian tersebut diperkuat menurut beberapa penelitian terdahulu oleh Ahmeda et al., (2020), Oftedal et al., (2018), Zhang et al., (2019), Iwu et al., (2019), Hahn et al., (2017), Nana ( 2012) (Christianingrum. \& Rosalina, 2017). Sedangkan terdapat pula penelitian lain seperti seperti pembelajaran kewirausahaan tidak berpengaruh terhadap minat berwirausaha, yang telah dijelaskan dari berbagai penelitian yaitu oleh Wardhani dan Rachmawati, (2019), Majdi 
(2012) , Rahmiyanti et al., (2019). Sementara itu, penelitian yang dilakukan oleh Febrianurdi dan Kurniawan (2017) menghasilkan kesimpulan bahwa motivasi berprestasi berpengaruh positif terhadap minat berwirausaha. Sebab, motivasi berprestasi berwirausaha mempunyai peranan penting dalam meningkatkan minat usaha seseorang. Hasil penelitian tersebut diperkuat menurut beberapa penelitian terdahulu oleh Wardhani (2019), Zhao et al., (2018), Bakadorova et al., (2019), Christopher J. Collins, (2009), Febrianurdi dan Kurniawan (2017), Aidha (2016), Tiwan, (2017), Rahmania et al., n.d. (2014). Sedangkan terdapat juga penelitian lain seperti motivasi berprestasi tidak berpengaruh terhadap minat berwirausaha, yang telah dijelaskan oleh Dzulfikri dan Kusworo (2019), Trisninawati (2012).

Perbedaan hasil penelitian yang belum tentu sesuai dengan kondisi dan situasi, lokasi, model, objek, subjek, waktu, variabel, analisis, sasaran, dan ataupun tujuan penelitiannya. Perlu adanya penelitian lanjutan mengenai kedua faktor tersebut. Hasil penelitian ini menggambarkan minat berwirausaha khususnya di lingkungan Pendidikan Akuntan FPEB UPI yang dapat digunakan oleh pihak-pihak terkait seperti mahasiswa atau alumni, serta dapat dijadikan sebagai pembanding terhadap teori-teori yang telah berkembang.

Paradigma yang digunakan dalam penelitian ini disesuikan dengan tujuan penelitian yang dilakukan yaitu untuk mengetahui pengaruh pembelajaran kewirausahaan dan motivasi berprestasi terhadap minat bewirausaha mahasiswa. Dari pernyataan tersebut, maka dapat dibuat suatu kerangka pemikiran yang dapat digambarkan sebagai berikut :

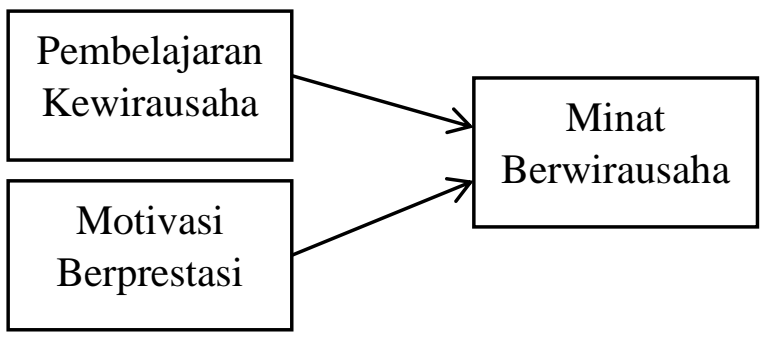

Gambar 2.2

\section{Model Hubungan Antar Variabel Penelitian}

Berdasarkan kerangka pemikiran yang telah diuraikan sebelumnya, hipotesis dalam penelitian ini dirumuskan sebagai berikut:

1. Pembelajaran kewirausahaan berpengaruh positif terhadap minat kewirausahaan mahasiswa pendidikan akuntansi FPEB Universitas Pendidikan Indonesia.

2. Motivasi berprestasi berpengaruh positif terhadap minat kewirausahaan mahasiswa pendidikan akuntansi FPEB Universitas Pendidikan Indonesia. 
METODE

Desain penelitian yang digunakan dalam penelitian ini adalah penelitian kuantitatif, menggunakan metode deskriptif dan verifikatif. Variabel dependen pada penelitian ini adalah minat berwirausaha, sedangkan variabel independen pada penelitian ini adalah pembelajaran kewirausahaan dan motivasi berprestasi

Item-item pengukuran variabel diadopsi dari peneliti-peneliti sebelumnya, dan respon terhadap item-item tersebut berupa penilaian pada 5 poin skala dari positif sangat rendah sampai dengan positif sangat tinggi. Pembelajaran kewirausahaan diukur dengan 9 indikator pengukuran yang bersumber Oemar Hamalik dalam (Pratomo et al., 2018) dan (Suherman, 2010). Motivasi berprestasi diukur dengan 4 item pengukuran yang bersumber dari McChelland (dalam Danim, 2004 : 33). Minat berwirausaha diukur dengan 3 item pengukuran yang bersumber dari Ramayah dan Harun (2005).

Populasi dan sampel penelitian ini adalah Mahasiswa Universitas Pendidikan Indonesia yang sejumlah 254 orang. Sampel penelitian dipilih dengan teknik simple random sampling, sehingga didapatkan sampel sebanyak 155 mahasiswa.
Pengukuran variabel dalam penelitian ini mengacu pada skala numerikal (numerical scale) Adapun pilihan angket yang akan diberikan terdiri dari angka 1 sampai dengan 5, dimana angka 1 dinyatakan untuk pernyataan positif paling rendah, angka 2 dinyatakan untuk pernyataan positif rendah, angka 3 dinyatakan untuk pernyataan positif sedang, angka 4 dinyatakan untuk pernyataan positif tinggi, dan angka 5 dinyatakan untuk pernyataan positif paling tinggi.

Metode Pengumpulan Data dilakukan menggunakan studi lapangan berupa kuisioner/angket. Data yang diperoleh dipilahkan, dinilai, dihitung dan dianalisis sesuai dengan rencana penelitian. Metode analisis data yang telah dilalui dalam penelitian ini meliputi Uji kualitas data (uji validitas dan reliabilitas), uji asumsi klasik (Normalitas, linearitas ,multikolonieritas, heteroskedastisitas), analisis regresi linear multiple, uji hipotesis, uji keberartian regresi (Uji F), Uji keberartian regresi (Uji t). 


\section{HASIL DAN PEMBAHASAN}

Penelitian ini dilakukan untuk mengetahui gambaran pembelajaran kewirausahaan dan motivasi berprestasi terhadap minat berwirausaha pada mahasiswa Pendidikan Akuntansi Angkatan 2016, 2017 dan 2018 FPEB Universitas Pendidikan Indonesia. Lalu bagaimana pengaruh pembelajaran kewirausahaan dan motivasi berprestasi terhadap minat berwirausaha pada mahasiswa Pendidikan Akuntansi Angkatan 2016, 2017 dan 2018 FPEB Universitas Pendidikan Indonesia. Pembahasan ini disusun berdasarkan hasil penyebaran angket dan interpretasi pengolahan data yang diperoleh dari lapangan untuk mengetahui hasil penelitian sesuai dengan teori yang digunakan.

Setelah melakukan pengolahan dan analis data dengan menggunakan bantuan software IBM SPSS Versi 25, selanjutnya dilakukan pembahasan mengenai hasil penelitian.

Hasil dari penyebaran angket dan mentabulasi data, secara umum, Hasil analisis deskriptif variabel pembelajaran kewirausahaan menunjukan bahwa nilai rata - rata untuk setiap indikatornya adalah 4,00 dimana nilai tersebut berada pada kategori tinggi. Untuk variabel pembelajaran kewirausahaan ini terdapat 9 indikator yang dijadikan sebagai acuan dan semua indikator tersebut memiliki nilai skor yang hamper mendekati skor ideal. Adapun skor rata - rata untuk setiap indikator tersebut $80 \%$ artinya berada dalam kategori tinggi. Maka, dari data tersebut dapat disimpulkan bahwa mahasiswa Pendidikan Akuntansi Fakultas Pendidikan Ekonomi dan Bisnis angkatan 2016-2018 Universitas Pendidikan Indonesia memiliki rasa keinginan yang besar dalam minat berwirausaha.

Hasil analisis deskriptif variabel motivasi berprestasi menunjukan bahwa nilai rata - rata untuk setiap indikatornya adalah 4,29 dimana nilai tersebut berada pada kategori tinggi. Untuk variabel motivasi berprestasi ini terdapat 3 indikator yang dijadikan sebagai acuan dan semua indikator tersebut memiliki nilai skor yang hamper mendekati skor ideal. Adapun skor rata - rata untuk setiap indikator tersebut $86 \%$ artinya berada dalam kategori tinggi. Maka, dari data tersebut dapat disimpulkan bahwa mahasiswa Pendidikan Akuntansi Fakultas Pendidikan Ekonomi dan Bisnis angkatan 2016-2018 Universitas Pendidikan Indonesia memiliki rasa keinginan yang besar dalam minat berwirausaha.

Hasil analisis deskriptif variabel minat berwirausaha menunjukan bahwa nilai rata - rata untuk setiap indikatornya 
adalah 4,00 dimana nilai tersebut berada pada kategori tinggi. Untuk variabel motivasi berprestasi ini terdapat 3 indikator yang dijadikan sebagai acuan dan semua indikator tersebut memiliki nilai skor yang hamper mendekati skor ideal. Adapun skor rata - rata untuk setiap indikator tersebut $79,9 \%$ artinya berada dalam kategori tinggi. Dilihat dari data tersebut dapat disimpulkan bahwa mahasiswa Fakultas Pendidikan Ekonomi dan Bisnis angkatan 2016-2018 Universitas Pendidikan Indonesia memiliki niat yang besar dalam berwirausaha dalam berwirausaha.

Dalam hasil analisis deskriptif, pembelajaran kewirausahaan yang dirasakan mahasiswa Pendidikan Akuntansi Fakultas Pendidikan Ekonomi dan Bisnis angkatan 2016-2018 Universitas Pendidikan Indonesia dalam berwirausaha berada pada kategori tinggi. Hal ini berarti mahasiswa memiliki suatu keyakinan bahwa dirinya merasa layak serta mampu untuk berwirausaha.

Hasil analisis verifikatif penelitian ini menunjukkan bahwa Berdasarkan hasil perhitungan uji t, pengaruh Pembelajaran Kewirausahaan terhadap Minat Berwirausaha diperoleh nilai $T_{\text {hitung }}$ sebesar 4,297 sementara $T_{\text {tabel }}$ pada taraf signifikansi 0,05 adalah 1,97569. Oleh karena itu diketahui bahwa nilai $T_{\text {hitung }}$
$(4,297)>T_{\text {tabel }}(1,96769)$, maka $H_{0}$ ditolak dan $H_{1}$ diterima. Sehingga hipotesis berbunyi terdapat pengaruh positif pembelajaran kewirausahaan terhadap minat berwirausaha. Hipotesis ini dapat diterima karena hasil pengujian menunjukan nilai yang positif, lalu hipotesis ini sesuai dengan teori dari Ajzen (2005) yang mengatakan dalam TPB (Theory of Planned Behavior) yang menyatakan bahwa pembelajaran kewirausahaan sebagai faktor yang paling mempengaruhi dalam peningkatan minat berwirausaha. Selain itu, hasil penelitian ini juga sesuai dengan penelitian terdahulu bahwa pembelajaran kewirausahaan memiliki pengaruh positif terhadap minat berwirausaha Kim dan Park (2019), Ahmeda et al., (2020), Oftedal et al., (2018), Zhang et al., (2019), Iwu et al., (2019), Hahn et al., (2017), Nana ( 2012) (Christianingrum. \& Rosalina, 2017).Namun penelitian ini bertentangan dengan 3 penelitian terdahulu dari yang menyatakan bahwa pembelajaran kewirausahaan tidak berpengaruh terhadap minat berwirausaha Wardhani dan Rachmawati, (2019), Majdi (2012) , dan Rahmiyanti et al., (2019).

Dalam hasil analisis deskriptif, motivasi berprestasi yang dirasakan mahasiswa Pendidikan Akuntansi Fakultas Pendidikan Ekonomi dan Bisnis angkatan 
2016-2018 Universitas Pendidikan

Indonesia dalam berwirausaha berada pada kategori tinggi. Hal ini berarti mahasiswa memiliki kecederungan yang tinggi untuk bertindak dalam hal berwirausaha.

Hasil analisis verifikatif penelitian ini menunjukkan bahwa Berdasarkan hasil perhitungan uji t, pengaruh Pembelajaran Kewirausahaan terhadap Minat Berwirausaha diperoleh nilai $T_{\text {hitung }}$ sebesar 4,572 sementara $T_{\text {tabel }}$ pada taraf signifikansi 0,05 adalah 1,97569. Oleh karena itu diketahui bahwa nilai $T_{\text {hitung }}$ $(4,572)>T_{\text {tabel }}(1,97569)$, maka $H_{0}$ ditolak dan $H_{1}$ diterima. Sehingga hipotesis berbunyi terdapat pengaruh positif motivasi berpestasi terhadap minat berwirausaha. Hipotesis ini dapat diterima karena hasil pengujian menunjukan nilai yang positif, lalu hipotesis ini sesuai dengan teori dari Ajzen (2005) yang mengatakan dalam TPB (Theory of Planned Behavior) yang menyatakan bahwa motivasi berprestasi sebagai faktor yang mempengaruhi dalam peningkatan minat berwirausaha. Selain itu, hasil penelitian ini juga sesuai dengan penelitian terdahulu bahwa motivasi berprestasi memiliki pengaruh positif terhadap minat berwirausaha Febrianurdi dan Kurniawan (2017) Wardhani (2019), Zhao et al., (2018), Bakadorova et al., (2019), Christopher J. Collins, (2009), Febrianurdi dan Kurniawan (2017), Aidha (2016), Tiwan, (2017), Rahmania et al., n.d. (2014), Febrianurdi dan Kurniawan (2017). Namun penelitian ini bertentangan dengan 2 penelitian terdahulu dari yang menyatakan bahwa motivasi berprestasi tidak berpengaruh terhadap minat berwirausaha Dzulfikri dan Kusworo (2019), Trisninawati (2012).

Berdasarkan uji statistik yang telah dilakukan menyatakan bahwa setiap variabel yaitu pembelajaran kewirausahaan $\left(X_{1}\right)$, motivasi berprestasi $\left(X_{2}\right)$ memiliki pengaruh yang positif terhadap minat berwirausaha dan kedua variabel tersebut memiliki keterkaitan satu sama lain.

\section{SIMPULAN}

Berdasarkan hasil penelitian dan pembahasan mengenai pengaruh pembelajaran kewirausahaan dan motivasi berprestasi terhadap minat berwirausaha mahasiswa Pendidikan Akuntansi FPEB Angkatan 2016, 2017, dan 2018 Universitas Pendidikan Indonesia, maka kesimpulan dalam penelitian sebagai berikut:

1. Mahasiswa Pendidikan Akuntansi Angkatan 2016, 2017, dan 2018 rata rata memiliki tingkat pembelajaran kewirausahaan yang tinggi, artinya mayoritas 
mahasiswa secara umum memiliki

keinginan yang besar dalam berwirausaha.

2. Mahasiswa Pendidikan Akuntansi Angkatan 2016, 2017, dan 2018 rata rata memiliki tingkat motivasi berprestasi yang tinggi, artinya mayoritas mahasiswa secara umum memiliki keyakinan yang besar dalam berwirausaha

3. Mahasiswa Pendidikan Akuntansi Angkatan 2016, 2017, dan 2018 rata rata memiliki tingkat minat berwirausaha yang tinggi, artinya mayoritas mahasiswa secara umum memiliki minat kewirausahaan yang sangat optimal untuk memulai dan menjalankan usaha sebagai wirausaha.

4. Pembelajaran kewirausahaan berpengaruh positif terhadap minat kewirausahaan mahasiswa Pendidikan Akuntansi UPI Angkatan 2016, 2017, dan 2018.

5. Motivasi berprestasi berpengaruh positif terhadap minat kewirausahaan mahasiswa Pendidikan Akuntansi UPI Angkatan 2016, 2017, dan 2018.

\section{DAFTAR PUSTAKA}

\section{Buku}

Ajzen, I. (2005). Attitides, personality, and behavior.

Danim, S. (2004). Motivasi, Kepemimpinan, dan Efektivitas Kelompok. PT Rineka Cipta.

Djaali. (2014). Psikologi Pendidikan (Cetakan VI). Bumi Aksara.

Suherman, E. (2010). Desain Pembelajaran kewirausahaan. Alfabeta.

\section{Jurnal}

Ahmeda, T., V.G.R., C., Jane, E. K., Francisco, L., \& Panagiotis, K. (2020). Entrepreneurship education programmes: How learning, inspiration and resources affect intentions for new venture creation in a developing economy. The International Journal of Management Education, 1-13.

Aidha, Z. (2016). PENGARUH MOTIVASI TERHADAP MINAT BERWIRAUSAHA MAHASISWA FAKULTAS KESEHATAN MASYARAKAT UNIVERSITAS ISLAM NEGERI SUMATERA UTARA. Journal of Knowledge Management, 2(2), 1-18. https://doi.org/10.1016/j.cya.2015.11. $\underline{011}$

Bakadorova, O., Hoferichter, F., \& Raufelder, D. (2019). Similar but different: social relations and achievement motivation in adolescent students from Montréal and Moscow. Compare: A Journal of Comparative and International Education, 00(00), $1-18$.

https://doi.org/10.1080/03057925.201 9.1576122 
Christianingrum., \& Rosalina, E. (2017). Effect of Entrepreneurship Learning on Interest in Entrepreneurship (Case Study in Student Management, Accounting and Sociology, University of Bangka Belitung). Integrated

Christopher J. Collins, P. J. H. \& E. A. L. (2004). (2009). The Relationship of Achievement Motivation to Entrepreneurial Behavior: A MetaAnalysis. Organ, The, 9285(930814856), 37-41. https://doi.org/10.1207/S15327043H $\underline{\mathrm{UP} 1701}$

Dzulfikri, A., \& Kusworo, B. (2019). Sikap, Motivasi, dan Minat Berwirausaha Mahasiswa di Surabaya. JKMP (Jurnal Kebijakan Dan Manajemen Publik), 5(2), 183. https://doi.org/10.21070/jkmp.v5i2.13 $\underline{10}$

Febrianurdi, A. B., \& Kurniawan, J. E. (2017). Hubungan motivasi berprestasi dengan minat berwirausaha mahasiswa psikologi. Psychopreneur Journal, 1(1), 76-84.

Hahn, D., Minola, T., Van Gils, A., \& Huybrechts, J. (2017). Entrepreneurial education and learning at universities: exploring multilevel contingencies. Entrepreneurship and Regional Development, 29(9-10), 945-974. https://doi.org/10.1080/08985626.201 $\underline{7.1376542}$

Handayani, T. (2015). Relevansi Lulusan Perguruan Tinggi Di Indonesia Dengan Kebutuhan Tenaga Kerja Di Era Global. Jurnal Kependudukan Indonesia, $\quad 10(1), \quad 53$. https://doi.org/10.14203/jki.v10i1.57
Hijriana, I., \& Purwaningsih, E. (2016). Pengaruh hasil belajar mata kuliah kewirausahaan terhadap minat berwirausaha mahasiswa pendidikan ekonomi fkip untan.http://ejournal.unipma.ac.id/index.php/equili brium/article/view/3836

Iwu, C. G., Opute, P. A., Nchu, R., EresiaEke, C., Tengeh, R. K., Jaiyeoba, O., \& Aliyu, O. A. (2019). Entrepreneurship education, curriculum and lecturer-competency as antecedents of student entrepreneurial intention. International Journal of Management Education, February, 100295. https://doi.org/10.1016/j.ijme.2019.03 .007

Kim, M., \& Park, M. J. (2019). Entrepreneurial education program motivations in shaping engineering students' entrepreneurial intention: The mediating effect of assimilation and accommodation. Journal of Entrepreneurship in Emerging Economies, 11(3), 328-350. https://doi.org/10.1108/JEEE-082018-0082

Majdi, M. Z. (2012). PENGARUH PEMBELAJARAN

KEWIRAUSAHAAN, INTERNALISASI NILAI KEWIRAUSAHAAN DI KELUARGA DAN MOTIVASI MINAT KEWIRAUSAHAAN. Jurnal Pendidikan, 7(2), 1-25.

Oftedal, E. M., Iakovleva, T. A., \& Foss, L. (2018). University context matter: An institutional perspective on entrepreneurial intentions of students. Education and Training, 60(7-8), 873-890. https://doi.org/10.1108/ET06-2016-0098 
Pratomo, R. P. K., Mulyadi, H., \& Utama, H. D. (2018). PENGARUH PEMBELAJARAN

KEWIRAUSAHAAN TERHADAP KESIAPAN BERWIRAUSAHA SISWA KELAS XII PASTRY SEKOLAH MENENGAH KEJURUAN NEGERI 9 BANDUNG. Journal of Business Management Education, 3(2), 67-77. https://doi.org/10.1017/CBO9781107 415324.004

Primandaru, N. (2017). Analisis FaktorFaktor Yang Berpengaruh Pada Minat Berwirausaha Mahasiswa. Jurnal Economia, $\quad 13(1), \quad 68$. https://doi.org/10.21831/economia.v1 $3 \mathrm{i} 1.13276$

Purwanto, I. (n.d.). pengaruh pelatihan kerja industri terhadap sikap kewirausahaan siswa kewirausahaan Siswa SMK Negeri 2 Majalengka. UPI Bandung.

Rahmania, M., Efendi, Z. M., \& Si, M. (2014). Pengaruh Pengetahuan Kewirausahaan, Praktik Kerja Industri dan Motivasi Berprestasi Terhadap Minat Berwirausaha Siswa Kelas XII Kompetensi Keahlian Pemasaran SMK Negeri Bisnis dan Manajemen Kota Padang. 1.

Rahmiyanti, S., Nuraisiah, R., \& (Universitas Banten Jaya). (2019). Pengaruh Pembelajaran Kewirausahaan Terhadap Minat Berwirausaha. 5(2), 103-111. https://doi.org/10.30653/003.201952. $\underline{74}$

Ramayah, T., \& Harun, Z. (2005). ENTREPRENEURIAL INTENTION AMONG UNIVERSITI SAINS MALAYSIA (USM) STUDENTS. International Journalof Management and Entrepreneurship, Vol. 1 pp.
Roro Aditya Novi W, Suci Rachmawati (2019).Pengaruh Pembelajaran Kewirausahaan Dan Motivasi Terhadap Minat Untuk Berwirausaha Mahasiswa Ikip Pgri Jember

Salahuddin, Akos, M., \& Hermawan, A. (2018). Meningkatkan Mutu Pendidikan Melalui Sumber Daya Manusia Dan Sarana Prasarana Di Mtsn Banjar Selatan 2 Kota Banjarmasin. Jurnal Ilmu Administrasi Dan Manajemen, 2(1), $1-13$.

Tiwan, T. (2017). PENGARUH MOTIVASI BERPRESTASI DAN KETERAMPILAN PRAKTIK TERHADAP MINAT BERWIRAUSAHA SISWA TEKNIK PEMESINAN. Jurnal Pendidikan Vokasional Teknik Mesin, Vol 5, No. http://journal.student.uny.ac.id/ojs/ind ex.php/mesin/article/view/7099

Trisninawati. (2012). HUBUNGAN MOTIVASI BERPRESTASI DENGAN MINAT BERWIRAUSAHA MAHASISWA(STUDI KASUS UNIVERSITAS BINA DARMA.

Wardhani, R. A. N., \& ,Rachmawati, S. (2019). Pengaruh pembelajaran kewirausahaan dan motivasi terhadap minat untuk berwirausaha mahasiswa ikip pgri jember. Equilibriu, 7(2), 5257.

Zhang, F., Wei, L., Sun, H., \& Tung, L. C. (2019). How entrepreneurial learning impacts one's intention towards entrepreneurship: A planned behavior approach. Chinese Management Studies, 13(1), 146-170. https://doi.org/10.1108/CMS-06$\underline{2018-0556}$ 
Zhao, X., Jia, L., \& Maes, J. H. R. (2018). Effect of achievement motivation on cognitive control adaptations. Journal of Cognitive Psychology, 30(4), 453465.

https://doi.org/10.1080/20445911.201 8.1467915

Peraturan Perundang-Undangan dan Dokumen Lainnya UNDANG-UNDANG REPUBLIK INDONESIA. (2003). UNDANGUNDANG REPUBLIK INDONESIA $\begin{array}{llll}\text { NOMOR } & 20 & \text { TAHUN } 2003\end{array}$ TENTANG SISTEM PENDIDIKAN NASIONAL. UNDANG-UNDANG REPUBLIK INDONESIA, 18(1), 2227.

http://luk.staff.ugm.ac.id/atur/UU202003Sisdiknas.pdf

\section{Artikel}

Badan Pusat Statistik. (n.d.). Pengangguran Terbuka Menurut Pendidikan Tertinggi yang Ditamatkan $1986 \quad$ - 2019. https://www.bps.go.id/statictable/200 9/04/16/972/pengangguran-terbukamenurut-pendidikan-tertinggi-yangditamatkan-1986---2018.html/

\section{Thesis}

Nana, S. (2012). Pengaruh Pembelajaran Kewirausahaan dan Pelatihan Kerja Terhadap Sikap Kewirausahaan: Studi Persepsional Siswa SMK SeKota Bandung. 